\title{
Raw wheat allergy: a case report
}

L Connors $^{1 *}$, G Lacuesta ${ }^{2}$, S Kapur ${ }^{2}, G$ Rex $^{2}$

From Canadian Society of Allergy and Clinical Immunology Annual Scientific Meeting 2009

Halifax, Canada. 22-25 October 2009

\section{Background}

There is evidence that individuals with milk and egg allergy may be able to tolerate the allergen in question if it is thoroughly heated. There is no published literature on raw versus cooked wheat allergy. We describe a case of hypersensitivity to raw wheat in an individual who is able to consume cooked wheat products.

\section{Methods}

The outpatient clinic chart of our patient was reviewed. Our patient gave consent to having her data presented in case report format.

\section{Results}

A 28 year-old female with a history of persistent allergic rhinitis and Arterial Tortuosity Syndrome had two episodes of anaphylaxis following a meal. In each instance she had ingested food cooked in batter. Skin prick tests to all foods ingested during the meals, including commercial wheat extract, were negative. Skin prick testing to wheat flour, white flour, the uncooked batter in question, as well as several commercial pancake mixes, were strongly positive. Our patient did not wish to undergo a double-blinded placebo controlled food challenge due to her underlying medical condition.

\section{Conclusions}

Our patient demonstrates IgE-mediated hypersensitivity to raw wheat, including uncooked batter. Her episodes of anaphylaxis occurred on ingestion of battered fish and chicken, which may have contained raw wheat if only partially cooked. We theorize that she is sensitized to a conformational epitope. Research is warranted in this area to further explore the possibility of raw wheat allergy.

\footnotetext{
* Correspondence: Iconnors@dal.ca

${ }^{1}$ McMaster University, Hamilton, ON, Canada
}

Author details

${ }^{1}$ McMaster University, Hamilton, ON, Canada. ${ }^{2}$ Dalhousie University, Halifax, NS Canada.

Published: 12 May 2010

doi:10.1186/1710-1492-6-S1-P26

Cite this article as: Connors et al:: Raw wheat allergy: a case report.

Allergy, Asthma \& Clinical Immunology 2010 6(Suppl 1):P26.
Submit your next manuscript to BioMed Central and take full advantage of:

- Convenient online submission

- Thorough peer review

- No space constraints or color figure charges

- Immediate publication on acceptance

- Inclusion in PubMed, CAS, Scopus and Google Scholar

- Research which is freely available for redistribution

Submit your manuscript at www.biomedcentral.com/submit 